Prof FEDERICO FERRETTI - BA, MA, PhD, Professore Ordinario di Geografia/Full Professor of Geography, Alma Mater Studiorum Università di Bologna, Dipartimento di Scienze dell'Educazione “G.M. Bertin”, Studio 70, Via Filippo Re 6, 40126 Bologna, Italy federico.ferretti6@unibo.it $\quad+39 \quad 051 \quad 2091609$ https://www.unibo.it/sitoweb/federico.ferretti6 ORCID ID: 0000-0002-5446-6522; Scopus ID: 55540917000; Web of Science ID: AAR-9553-2021; Google Scholar; ResearchGate; Academia.edu; LinkedIn; CNPq-Lattes.

\title{
Geographies of revolution: prefiguration and spaces of alterity in Latin American radicalism
}

Abstract: This paper discusses geographies of revolution and their potentialities for providing new notions of space to critical, subaltern and decolonial geopolitics. It does so by addressing a virtually unknow case, that is works of Cuban revolutionary and geographer Antonio NuñezJiménez (1923-1998), especially his 1959 Geografía de Cuba. This book was published during the revolutionary period, after the fall of dictator Fulgencio Batista and before the 1961 official 'socialist' turn of the new (authoritarian) Castroist regime. According to respected scholarship, the original inspiration of the Cuban revolution was democratic and anticolonialist, and its initial components quite heterogeneous. My argument is twofold. First, I contend that revolutions occur independently from narrow ideological labels that were imposed later, and geographies of revolution express their performative potentialities for prefiguring new worlds independently from the (re)establishment of post-revolutionary states. Second, I suggest that Jiménez's elaborations on the Cuban Monte as a (revolutionary) space of alterity can nourish decolonial geopolitics which are alternative to European ideas of bounded territoriality. Corresponding to the rough and 'uncivilised' hinterland where historical experiences of Indio and Afro-Cuban insurgences took place, the Monte became a concept defining subversion and alterity through Jiménez's claims that these early insurgences found their continuators in the nineteenth-century anticolonial fighters and in the 1950s guerrillas. By addressing Jiménez's original writings, which were mostly never translated into English, I also extend current literature rediscovering critical and radical geographies beyond their Northern and Anglo-American 'core'.

Keywords: Geographies of Revolution; Radical Geographies; Spaces of Alterity; Critical Geopolitics; National Imagination

F. Ferretti, 2022: "Geographies of revolution: prefiguration and spaces of alterity in Latin American radicalism", Environment and Planning C, Politics and Space Online first: https://journals.sagepub.com/doi/full/10.1177/23996544211063163 [author's version] 
This paper discusses geographies of revolution, contributing to new and decolonial understandings of critical geopolitics. It does so by analysing a case that is virtually unknown to English-speaking scholarship, that is the work of Cuban geographer and revolutionary Antonio Nuñez-Jiménez (1923-1998). First trained as a physical geographer, Jiménez was the author of an ambitious Geografia de Cuba in 1954: yet, all the printed copies and even the moulds of this book were confiscated and burnt by the infamous Military Intelligence Service (SIM) of dictator Fulgencio Batista (1901-1973), who deemed Jiménez's book subversive, because it overtly advocated agrarian reform. This sensitive matter was not considered as a legitimate content for a geography textbook given that, for most authoritarian regimes, sciences should be 'neutral' or 'apolitical' to render them innocuous and unable to expose social contradictions.

In 1958-59, Jiménez was a protagonist of the Cuban Revolution, serving as a captain in the Rebel Army, where he joined Ernesto 'Che' Guevara (1928-1967) in the last phases of the war that led Fidel Castro (1926-2016) to seize power (Thomas, 1971:1027). Few copies of Jiménez's book had survived in the 'backpacks' (Jiménez, 1959:8) ${ }^{1}$ of the guerrillas, and a second edition was published in 1959, with Castro's afterword. Beyond the exceptionality of this story, what emerges from the reading of this impressive volume of 624 two-column pages is that it is undoubtedly a geography of revolution, at the same time for its contents and its contexts. Hitherto, Jiménez's work has not raised much attention among geographers, with few exceptions including a recent chapter by Verónica Ibarra and Edgar Sánchez (2020). Rediscovering critically Jiménez's geography can provide original insights into the relations between space and politics for reframing geopolitical debates about geography's political relevance.

This paper extends and connects scholarship on critical geopolitics, geographies of revolution and Caribbean anticolonial histories. In their pioneering work on Geography and Revolution, Charles W.J. Withers and David N. Livingstone discuss the polysemous nature of the term

\footnotetext{
${ }^{1}$ All quotes from texts in languages other than English have been translated by the author.

F. Ferretti, 2022: "Geographies of revolution: prefiguration and spaces of alterity in Latin American radicalism", Environment and Planning C, Politics and Space Online first: https://journals.sagepub.com/doi/full/10.1177/23996544211063163 [author's version]
} 
'revolution', which was first used in astronomy and can be understood as scientific revolution, technical revolution or political revolution. Geographical approaches can apply to all these kinds of revolutions, under the forms of 'geography of revolution and geography in revolution' (Withers and Livingstone, 2005:1). While Jiménez's works can match both of these cases as I explain below, Withers and Livingstone discuss how (although heterogeneously) 'geography books were used as vehicles of debate' (Withers and Livingstone, 2005:2) in a number of political revolutions, dating back from the seventeenth-century English revolutions and the eighteenth-century French and American ones. The authors note that: 'Political revolutions regularly come with geographical qualifiers: English, Chinese, Cuban, French, Iranian, Mexican, Russian, to name only a few' (Withers and Livingstone, 2005:239). This shows the importance of building geographical imageries for political purposes, including making revolutions.

As for geographers' participation in political revolutions, Mike Heffernan has studied the case of French geographer Edme Mentelle (1730-1816), who promoted 'a program of republican geography books' (Withers and Livingstone, 2005:239) to be used in all French schools when the new revolutionary regime was established in the 1790s. Unlike Jiménez, Mentelle was not actually what today we might call an activist, as he seemed to move towards the new regime in a rather opportunistic way. Yet, he had the merit, or the cleverness, of understanding how deeply: 'The Revolution represented a fundamental break with the past and had ushered in entirely new conceptions of space and time [that] had "annihilated" the old geographies and temporalities. [As French historian Jules Michelet argued:] "There were no longer any mountains, rivers, or barriers between men"' (Heffernan, 2005:277). While Jiménez's works also inspired revolutionaries rather than simply describing their accomplishments, Mentelle's commitment to teach the new regional geographies of revolutionary France and to organise new educational institutions such as the Ecole normale in agreement with the Convention nationale, anticipated Jiménez's preoccupation of making geography participate to the construction of revolutionary Cuba. This included the establishment of a new educational system.

F. Ferretti, 2022: "Geographies of revolution: prefiguration and spaces of alterity in Latin American radicalism", Environment and Planning C, Politics and Space Online first: https://journals.sagepub.com/doi/full/10.1177/23996544211063163 [author's version] 
More recently, Claudio Minca has contended that geography should 'make revolution', quoting Italian geographers such as Giuseppe Dematteis and Massimo Quaini, who argued that the performativity of geographical knowledge makes it 'intrinsically revolutionary' and potentially 'subversive', as geography is both 'a description of existing things and a critique to what exists' (Minca, 2019:8). Minca discusses the link between geography and revolution to extend the geopolitical debates that followed John Agnew's calls to exit the 'territorial trap' (Agnew, 2010; Reid-Henry, 2010). Minca addresses these matters with special reference to migrations, which are confirming the political and ontological limitations of the territorial state. This implies that geography should elaborate: 'An alternative spatial and political paradigm [which] can overtake the dreadful alliance between a territorial nation state ... and the topographies of a global capitalistic space' (Minca, 2019:18), including their implications in terms of oppression, social control and authoritarian (bio)politics. Therefore, geography is a key player in revolutions.

Furthermore, this paper extends recent literature on radical geography arguing for the need of going beyond the classical Anglo-American core in rediscovering recent histories of critical and radical geographies (Barnes and Sheppard, 2019; Craggs and Neate, 2020; Clayton, 2020, Ferretti and Pedrosa, 2018). These works first address critical geographies from the Global South and from linguistic and cultural areas other than the dominant ones, challenging the monolingualism and parochialism of that 'core'. I also extend the debates that are ongoing on decolonising geographical knowledges by considering different 'epistemes', as suggested by the Modernity-Coloniality-Decoloniality (MCD) collective, among other references that are increasingly current in English-speaking scholarship, such as Black studies and indigenous feminisms (Noxolo, 2017; Radcliffe, 2017). To find different theoretical inspirations than classical European authors, decolonial scholars value sources such as indigenous thinkers and anti-racist activists, including the Black leaders of the 1791-1804 Haitian Revolution, Toussaint Louverture and Jean-Jacques Dessalines (Mignolo and Escobar, 2010). While Haiti is recognised as the most paradigmatic case of a non-European revolution where Black slaves fought for themselves overtaking the contradictions of European revolutions (James, 1938; Buck-Morss, 2009; Shilliam, 2017), Cuba represented a quite different case given that, as Ada

F. Ferretti, 2022: "Geographies of revolution: prefiguration and spaces of alterity in Latin American radicalism", Environment and Planning C, Politics and Space Online first: https://journals.sagepub.com/doi/full/10.1177/23996544211063163 [author's version] 
Ferrer notes, slavery was even strengthened there during the Haitian events (Ferrer, 2014), as I discuss below.

My argument is twofold. First, revolutions happen independently from narrow ideological labels that may have been imposed later and, in revolutionary processes, geographies of revolution play performative and prefigurative roles that are likewise resistant to univocal ideological schemes. That is, geography can account for the diversity of revolutions as situated practices that do not occur in the same way in different places, cultures and historical periods. Having been written before the 'socialist' (more specifically Marxist) turn of the Cuban regime, which took place officially in 1961, the 1959 Geografía de Cuba is replete with claims for social justice and for national/anticolonial liberation, but it does not mention at all Marxism or Leninism, that is the ideologies with which revolutionary Cuba is commonly associated. Studying Jiménez's book as a contribution to build Cuban national and anticolonial imageries complements classical scholarship on the invention of national identities (Anderson, 1991) and the role of geography in these heterogeneous processes (Hooson, 1994). These allowed the construction of what Benedict Anderson defined as 'anticolonial imagination' (Anderson, 2007), a complex and transnational mixing of nationalism and socialistic tendencies including works of Cuban anti-colonial 'hero' José Martí (1853-1895). Contributing to these imaginaries, geographies of revolution express their prefigurative potentialities beyond the eventual outcomes of revolutionary processes establishing post-revolutionary (more or less authoritarian) states.

Second, current decolonial geopolitics challenging European ideas of bounded territoriality can find inspiration in Jiménez's elaborations on the Cuban Monte-the mountainous and 'uncivilized' countryside serving as a refuge for rebels or marginalised communities, as a space of alterity. In those spaces of otherness, the geographer situated a genealogy of the Cuban Revolution consisting in early slaves' insubordination and subaltern insurgency. Drawing upon Latin American anticolonial imaginations, Jiménez's work helps understanding the plurality of geopolitical traditions: they did not only serve the establishment of territorial statehood (Elden, 2013), as they could also serve its revolutionary questioning, upsetting and disruption. Traditionally identified with the 'rough' hinterlands, opposed to the colonised and

F. Ferretti, 2022: "Geographies of revolution: prefiguration and spaces of alterity in Latin American radicalism", Environment and Planning C, Politics and Space Online first: https://journals.sagepub.com/doi/full/10.1177/23996544211063163 [author's version] 
Europeanised coastal cities in most of Spanish-speaking Latin America, the Monte corresponds to a non-conventional and non-European idea of spatiality and territoriality, having been historically populated by Indios, unruly African slaves, guerrilleros and other rebels. These different spatialities can be connected with ethics of marronage and insubordination (Roberts, 2015) to suggest alternatives to European notions of territory and to extend scholarship on subaltern and liminal geopolitical actors (Ince and Barrera 2016; McConnell 2016; Sidaway, Mamadouh and Power 2013; Sharp 2011).

In this vein, recent studies on geographies of marronage highlight the intrinsic links between communities of fugitive slaves such as palenques and quilombos and the production of alternative geographies in places such as marshes, mountains and forests that: 'Marginalized, hunted, and exploited people have made habitable — areas where communities have taken a desire for liberation and merged it with an ignored and undervalued environment' (Wright, 2020:1135). Similarly, Latin-American notions of territories in resistance consider space as not incidental, but intrinsic, to the strategies of social movements (Halvorsen, Fernandes and Torres 2019; Souza, 2016; Zibechi, 2012). Therefore, Latin American ideas of spatiality can nourish international debates on decolonising the concept of territory (Halvorsen 2019).

Finally, several authors note the contradiction between the prominent roles that Black insurgency played from the 1868-1898 cycle of struggles for Cuban national independence (Ferrer 1999) to the 1959 Revolution, and the substantial failure of the Castroist regime in definitively getting rid of racial discrimination (Fuente, 2001; Clealand, 2017; Kempf 2017). This did not prevent Jiménez from envisaging a clear continuity between early indigenous, Black and anti-colonial insurgencies and the revolution of his day, which he considered to have originated in the Monte to foster Cuban revolutionary narratives on the 1959 revolution as the culminating point (and assertedly definitive victory) of anti-colonial struggles ongoing since the beginning of Spanish domination in the island.

In the first part of my paper, I discuss the historical and geographical contexts of the plural Cuban insurgent and anti-colonial traditions in which Jiménez's life and works are inserted. In the second part, I discuss the 1959 edition of Geografía de Cuba as a prefigurative instrument

F. Ferretti, 2022: "Geographies of revolution: prefiguration and spaces of alterity in Latin American radicalism", Environment and Planning C, Politics and Space Online first: https://journals.sagepub.com/doi/full/10.1177/23996544211063163 [author's version] 
for making revolution, that is building national and anti-colonial imaginaries of the island. In the third part, I discuss Jiménez's geopolitics of the Monte as a contribution for decolonial geopolitics to build different and subversive grammars of space, opposed to the traditional statist and territorial ones.

\section{1 - Jimenez's Geography, and the plurality of insurgent traditions}

In October 1959, the publication of the new 'revolutionary' edition of Jimenéz's Geografía de Cuba was directly patronised by the leaders of the Cuban Revolution, eventually Raúl Castro and Camilo Cienfuegos (1932-1959), who did 'inaugurate ... Geography of Cuba, which had been burnt by Batista's tyranny and was now adopted as a textbook' (Jiménez, 1998b:3242). While this shows the strategic importance of a 'new' geography for a 'new' Cuba, to understand this work one needs to contextualise Jiménez's geography within the histories and geographies of Cuban revolutionary traditions, which are very diverse, although they can be always associated with some kind of anti-colonial imagination. This section aims at providing these contexts before further developing my arguments.

Cuban revolutionaries of the most diverse tendencies claim the experience of the anti-colonial struggle against Spain that took place in the second half of the nineteenth century (Anderson, 2007; Fuente, 2001; Ferrer, 1999). They generally recognize Martí as the 'noble father' of Cuba's independence, and sometimes of Cuban socialism. Although Martí, in addition to addressing 'issues of social justice, racial equality and independence ... also stressed the need for class cooperation' (Shaffer, 2019:55), his prestige was recognised also in the most radical groups. As historian of Cuban anarchism Kirwin Shaffer argues, this was the case with most of the anarchists, who incorporated Martí 'into their work' (Shaffer, 2019:62), concurrently criticising nationalist and governmental uses of this figure. While exposing the importance of anti-colonial imaginations (against the Spanish domination and later against US neocolonialism) for all socialistic movements in Cuba, Shaffer also highlights the plural uses of definitions such as socialism. 'An undoubtedly vague term in the first decade of the twentieth century, [it] could have meant anything from a parliamentary socialist to the most radical of anarchists' (Shaffer, 2019:9).

F. Ferretti, 2022: "Geographies of revolution: prefiguration and spaces of alterity in Latin American radicalism", Environment and Planning C, Politics and Space Online first: https://journals.sagepub.com/doi/full/10.1177/23996544211063163 [author's version] 
In Cuba, early anarchist movements adopted anticolonial national imageries. For Shaffer, anarchists 'Cubanized anarchism', creating 'their own specific sense of cubanidad (Cubanness)' (Shaffer, 2019:2), although continuing to propose 'an internationalist vision for the island' (Shaffer, 2019:24). Importantly, these broad ideas of nation were inserted in transnational networks in which also Spanish anarchists like Pedro Esteve supported 'Cuba's anticolonial struggle' (Shaffer, 2019:57). As magisterially discussed by Anderson (2007), activists from transnational and multilingual networks worldwide did the same. Anticolonialism, anarchism, syndicalism and heterogeneous forms of socialism concurred to build the Cuban workers' movement, while it was only in the 1960s that orthodox Marxism became hegemonic (Fernández, 2001; Kapcia, 2014; Farber, 2006).

Anticipating later mobilisations of geographical and naturalistic metaphors to define Cubanness, some components of these movements mobilised the notion of 'naturism' in opposition to capitalistic modernity, embracing a lifestyle where: 'Being in harmony with Nature [meant] to save the laborers from the increasingly industrialized character of Cuba' (Shaffer, 2019:14). In the early twentieth century, this echoed the engagement of anarchist geographers such as Elisée Reclus (1830-1905), who was a very famous figure in Spanishspeaking socialist circuits. The partisan of an alliance between social and environmental causes (Reclus, 1908), Reclus was quoted as a 'genius' (Jiménez, 1998a:223) by Jiménez, who dedicated a chapter of his book Hacia una cultura de la naturaleza to the French geographer's work, implicitly dissenting from Karl Marx who, consistently with his anti-anarchist positions, had defined Reclus, in Jiménez's words, 'a charlatan' (Jiménez, 1998a:224). Importantly, Jiménez mobilised Reclus's ideas in his attempts to match what Shaffer defines: 'A long tradition of imagining Cuba as an "island of dreams" where humanity could create a free, healthy, educated, and egalitarian beacon for global liberation' (Shaffer, 2019:233).

Another point characterising Reclus's geography and the entire anarchist tradition was echoed by Jiménez, that is the idea of changing society through education, which characterised the international movement known as Pedagogía Libertaria (Ferretti, 2018). Cuban anarchists, and later 'leftists in general', opened 'schools in every part of Cuba where they offered educational alternatives to state-operated and religious-affiliated institutions' (Shaffer, 2019:194). Jiménez

F. Ferretti, 2022: "Geographies of revolution: prefiguration and spaces of alterity in Latin American radicalism", Environment and Planning C, Politics and Space Online first: https://journals.sagepub.com/doi/full/10.1177/23996544211063163 [author's version] 
recognised Reclus's pedagogical inspiration in defining the 'Earth as the educator' (Jiménez, 1998a:224) of humankind to build equality and justice through environmental consciousness. Yet, while some historical insights from the anarchist culture continued to circulate indirectly through geography and 'naturalistic' writing, the material participation of the anarchist movement to the Cuban revolution was violently repressed after 1959.

On this matter, authors such as Shaffer, and Frank Fernández, match the positions of Vsevolod Mikhailovich Eichenbaum (1882-1945) known as Volin, the author of The Unknown Revolution. This book explains how anarchists and revolutionary socialists had been among the protagonists of the Russian revolution between 1917 and 1921 and were then repressed by the Bolshevik dictatorship, whose official historiography minimised their role (Volin, 2019). These authors show how something similar happened in the years that followed the empowerment of Castro and his $26^{\text {th }}$ of July Movement (hereafter M26J) in Cuba, when the anarchists' role was 'downplayed or distorted' (Shaffer, 2019:224) by the official propaganda, despite their collaboration with the wider revolutionary movement, which included 'using their hall to train some of Castro's M26J members to use firearms' (Shaffer, 2019:232).

In 1959-60 the anarchists, who published journals such as Solidaridad Gastronómica and El Libertario, became increasingly disagreeable to the government mainly due, according to Fernández, to communist 'elements which had infiltrated' (Fernández, 2001:52) the M26J. Like other works that I mention below, these histories of political dissidence show that the earliest phases of the consolidation of Castro's regime were far from being ideologically hegemonized by Marxism. At that moment, the early communist party, the PSP (Partido Socialista Popular), which merged with the M26J only in 1961, was just a component in a wider movement. For Fernández, spaces for political dissidence were dramatically restricted after the 1961 failed North American invasion in Playa Girón (Bay of Pigs). This event gave to the government 'the excuse it needed to totally liquidate the internal opposition, which of course included the anarchists' (Fernández, 2001:59). While reasons and modalities of Castro's 'conversion' to Marxism and his alliance with the Soviet Union are still the object of complex debates, it is worth noting the gradual and not ineluctable nature of this shift.

F. Ferretti, 2022: "Geographies of revolution: prefiguration and spaces of alterity in Latin American radicalism", Environment and Planning C, Politics and Space Online first: https://journals.sagepub.com/doi/full/10.1177/23996544211063163 [author's version] 
Samuel Farber discusses how: 'The rapid evolution of the Cuban Revolution from a multiclass anti-dictatorial political movement to "socialist revolution," as Fidel Castro officially declared in April 1961, remains a puzzle' (Farber, 2006:1). While the suspect that Castro had 'hidden' his 'Marxist-Leninist' inspiration until the 1960s for opportunity reasons is part of wider conspiration theories that style the Cuban revolution as a 'Soviet plot' against the USA, authors like Farber stress the initial distances between the Cuban filo-Soviet communists and the M26J. This was also motivated by the fact that: 'The Cuban Communists allied with Batista in the late 1930s in exchange for the governments granting the party official control of the trade unions' (Farber, 2006:38). Cuban dissidents even denounced the 'recycling' of some communist politicians 'who had worked with Batista' (Shaffer, 2019:232) in the new revolutionary government. 'The old Cuban Communists had a very compromised political history and questionable revolutionary legitimacy because they physically joined the guerrilla ... a few months before victory' (Farber, 2006:126). According to Farber, among the leaders who became prominent after 1959 , only a small minority had pre-revolutionary ties with the PSP.

A respected historian of Cuba, Hugh Thomas (1971), confirmed that the social and political composition of the earliest groups that accompanied Castro was heterogeneous. In what Antoni Kapcia identifies as the 'triad' of the most influential leaders, the closest to Marxism was not Fidel, but his younger (and less popular) brother Raúl, and to some extent Che Guevara (Kapcia, 2014). Kapcia notes how even Guevara's Marxism can be considered as somehow unorthodox. Following the empirical experience of Cuba, Guevara realised that 'objective conditions' were not the only possible pre-condition for revolution, because: 'Political consciousness itself (conventionally seen as part of the "superstructure" rather than the base) could substitute for objective conditions' (Kapcia, 2014:33). According to Farber, Guevara himself, initially, 'did not see [Fidel] Castro as belonging to that same camp. On some occasions, even Raúl Castro expressed doubts about his brother's political intentions' (Farber, 2006:60). For Farber, Fidel's approach was characterised by pragmatism rather than ideology, including the 'brief honeymoon' (Farber, 2006:79) he had with the US Congress during a diplomatic visit to the United States in April 1959.

F. Ferretti, 2022: "Geographies of revolution: prefiguration and spaces of alterity in Latin American radicalism", Environment and Planning C, Politics and Space Online first: https://journals.sagepub.com/doi/full/10.1177/23996544211063163 [author's version] 
To put Jiménez's geography in its contexts, it is necessary to consider what Farber defines as the understudied 'existence of a number of political currents within the revolutionary regime, at least during its first years in power' (Farber, 2006:114). In this situation, Fidel 'delayed as much as possible the inclusion of open Communists in his government for both domestic and foreign policy reasons' (Farber, 2006:154). Jiménez is considered as one of the earliest 'communists or near-communists' (Thomas, 1971:1214) in the group, having been (at least temporarily) a PSP member before the Revolution. Despite having joined the armed guerrilla only few weeks before the final victory, Jiménez was well inserted in the revolutionary leadership at the highest levels, including 'Fidel's small groups' (McKelvey, 2017:105). The team that collaborated to redact the land reform law in 1959 was composed by: 'Fidel, Guevara, the geographer ... Jiménez, Vilma Espin and Alfredo Guevara Valdes' (Kapcia, 2014:74). Interestingly, Kapcia argues that, among the former PSP activists, Jiménez was 'far from orthodox' (Kapcia, 2014:74) and describes Jiménez's positions as an 'unusual combination of radical ideas and maverick Communism' (Kapcia, 2014:97). Most of the historians who mentioned Jiménez notice the importance of the roles that he played in the agrarian reform and in the early foreign policies of revolutionary Cuba, for which he accomplished the first diplomatic missions in Europe and the USSR.

This situation clashes with the fact that Jiménez never became famous like other 'heroes' of the revolution, such as the Castros, Guevara or Cienfuegos. Historians of the Cuban Revolution even suggest that, despite his recognition as a guerrilla veteran, he was somewhat marginalised. In 1962: 'Castro removed Antonio Núñez Jiménez (who was obviously not up to the job) as director of the National Agrarian Reform Institute' (Skierka, 2004:121). Strikingly, this happened although this reform was 'mainly written' (Thomas, 1971:1215) by the geographer. Thomas argues that Jiménez was deemed rather a propagandist than an organiser by Fidel and, when the political power began to be solidly in place, he was sent to fulfil less delicate tasks such as writer and director of cultural institutions. Yet, only further studies can clarify the sudden downgrading of this important figure of Cuban revolutionary

Moreover, the politically hybrid nature of the early phases of the Cuban revolution is confirmed by the Land Reform law. This legislative act was undoubtedly part of the Cuban revolution,

F. Ferretti, 2022: "Geographies of revolution: prefiguration and spaces of alterity in Latin American radicalism", Environment and Planning C, Politics and Space Online first: https://journals.sagepub.com/doi/full/10.1177/23996544211063163 [author's version] 
but it was 'not Communist, because it emphasized land redistribution' (Farber, 2006:81) rather than collectivisation. This concept is further emphasized by Jiménez's own recollections En marcha con Fidel. Although these writings are highly celebrative, they reveal some useful details. For instance, accompanying Fidel in a speech to some peasants in March 1960, Jiménez noticed how: 'In these early times of revolutionary power, due to concrete realities, it was forbidden to Fidel to talk about Marx, Engels or Lenin: nevertheless, he found an efficient instrument in the Bible' (Jiménez, 1998b:1030). Unless one is so naïve to really believe that Lenin and the Bible are the same, or that Fidel was so shy to hide his own ideology during his campaigns as a triumphant revolutionary leader, it is clear that Jiménez's (retrospective) phrasing is a euphemism to mean that the ideological tools of the Cuban Revolution were not yet definitively chosen, and Fidel was still more comfortable with the notions that he had assimilated through his Catholic education (Skierka, 2004).

These recollections also provide insights on Jimenez's foreign missions. In May 1960, Jiménez was sent to Moscow to personally deliver 'the first letter that Fidel wrote to Khrushchev' (Jiménez, 1998c:1788). During this mission, where Jiménez was granted an honorary PhD in Geography at the Lomonosov University, there was no point for discussing MarxismLeninism, but only the Soviets' satisfaction for the rising 'of an independent and democratic republic' (Jiménez, 1998c:1843) in Cuba. Arguably, Khrushchev still refused any excessive proximity with Cuba for reasons of Cold War diplomacy, whose dangers would be frightfully exposed by the later 1962 missile crisis (Skierka, 2004). Importantly, Jiménez's diplomatic mission was not limited to Moscow, as he also met Pope John XXIII, giving him a 'copy of the Geografía de Cuba' and showing 'the pictures of the peasants in their so lamentable state of misery. I explained to him that these scenes were disappearing from our fields, thanks to the agrarian reform' (Jiménez, 1998c:1916).

As I discuss in the next section, Geografía de Cuba was a scholarly work arguing for the needs of agrarian reform and complete decolonisation that can be fully considered as a geography of revolution. Advocating agrarian reform also implied a critique of the environmental determinism through which mainstream narratives justified the poverty of most 'Third World' countries as a 'natural' flaw, rather than as a socially and colonially engineered situation. Again

F. Ferretti, 2022: "Geographies of revolution: prefiguration and spaces of alterity in Latin American radicalism", Environment and Planning C, Politics and Space Online first: https://journals.sagepub.com/doi/full/10.1177/23996544211063163 [author's version] 
with celebratory tones, Jiménez claimed that: 'Geographical fatalism is falling down ... through the victorious example of the Cuban Revolution [showing] that a united people can challenge the immense power of imperialism' (Jiménez, 1998b:1003). Beyond propaganda, what is crucial in this statement is that, in Cuba, a geography of revolution had to challenge the alleged inferiority of tropical countries and their dependency from Northern recipes for 'development' - which indeed meant neo-colonialism.

\section{2- A prefigurative geography of revolution}

As Withers and Heffernan contend, revolutions are situated, and Jiménez's geography is a good way to understand the spatiality of the Cuban Revolution in its national and international contexts, including its Latin American dimension. Although his works seem to have been substantially neglected by geographers, Jiménez was in touch with some of the most prominent Latin American critical geographers of his time, such as Brazilian Josué de Castro ${ }^{2}$ and Mexican Angel Bassols-Batalla (Delgadillo, 2015). Jiménez's geography participated in debates that these authors led, such as the agrarian reform, which was one of the key points of Castro's geographies of hunger. Through his political and scholarly work, the Brazilian geographer supported the peasants' leagues of North-eastern Brazil claiming for land reform against monoculture an latifundium and, like Jiménez, advocated national sovereignty over his land's resources (Davies, 2019; Ferretti, 2021; Ibarra and Sánchez, 2020). Castro was a supporter of the Tricontinental Conference which took place in Cuba in 1966, gathering an heterogeneous array of anticolonial guerrilla movements and governments of newlydecolonised states (Mahler 2018). Likewise, Jiménez's last documented diplomatic missions were strictly associated with one of the key points of his revolutionary geography, that is anticolonialism. It was the case with his talks to African anticolonial leaders such as Guinean president Sékou Touré and the Algerian activists of the Front de Libération Nationale (Thomas, 1971:1317). While standing in continuity with the transnational traditions of Cuban and Latin American anticolonialism, these activities contributed to international intellectual networks currently addressed by geographical scholarship on decolonisation (Craggs 2018).

\footnotetext{
${ }^{2}$ Nanterre, La Contemporaine, Archives du CID, FD 446, 15-05, Castro to Nuñez Jiménez, 17 July 1969.

F. Ferretti, 2022: "Geographies of revolution: prefiguration and spaces of alterity in Latin American radicalism", Environment and Planning C, Politics and Space Online first: https://journals.sagepub.com/doi/full/10.1177/23996544211063163 [author's version]
} 
In this context, Geografía de Cuba provided a staunchly anticolonial idea of revolution. The book was a full part of the revolutionary fabric, given his author's direct involvement with preand post-revolutionary politics, and its 1959 edition is an intriguing volume. In the Introduction, the author claimed that few copies of the first edition survived and were circulated 'in the prisons, in clandestine activity and even in the battlefield'; some pages were also mimeographed to serve 'in the rebel school of Escambray, as revolutionary textbook' (Jiménez, 1959:8). The invasion of the Lex printing shop by the SIM to burn the first edition was motivated, according to Jiménez, by: 'Our arguments in defence of the Cubanization of national resources [and] our explicit request of an agrarian reform' (Jiménez, 1959:8). The 1959 edition had an afterword by Fidel Castro, who endorsed geography as one of the knowledges that had to be studied in the new Cuban schools. The Líder Máximo solemnly asserted that the person 'who does not study is not a good revolutionary' (Jiménez, 1959:611), although he did not enter any specific debate on geography as a discipline. Jiménez expressed special acknowledgements to the typographer of the Lex publishing house, who had to 'stoically resist the interrogatories' (Jiménez, 1959:619) of Batista's political police when the printing shop was invaded. Thus, writing and printing this book in the early 1950s was explicitly styled as an act of resistance under the dictatorship.

The book has five main chapters: the first on physical geography, geology an climate; the second on Cuba's 'human geography'; the third on Cuba's 'natural resources' including agriculture; the fourth on economic geography, with a special emphasis on manufacture; the fifth, and longest one, was called 'regional geography' and systematically described the country, dividing it in 6 regions (Pinar del Rio, Habana, Matanzas, Las Villas, Camagüey, and Oriente). This way of proceeding was clearly influenced by the traditional monographs proceeding from the French School of the Géographie humaine, a main reference for most of Latin American geographers of Jimenez's generation. This inspiration can partially explain Jiménez's tendence to underplay urban environments in his book. Although urban struggles were undoubtedly part of the Cuban revolution, only 2 pages of 624 are dedicated to the city of Habana. While this sort of ruralism equally echoes the author's adhesion to the myths of rural guerrilla, this remains a limitation of Jiménez's work, although this should not prevent contemporary appreciations of the insights coming from it.

F. Ferretti, 2022: "Geographies of revolution: prefiguration and spaces of alterity in Latin American radicalism", Environment and Planning C, Politics and Space Online first: https://journals.sagepub.com/doi/full/10.1177/23996544211063163 [author's version] 
Having been impossible to locate any surviving copy of the first edition, it is difficult to exactly discern what was already included and what was added in 1959, beyond some points where revolutionary accomplishments of that year were explicitly mentioned, and other parts that had been clearly written in the pre-revolutionary context. Given the huge dimensions of the book, one can argue that most of it was written and designed before the revolution and that the interpolations that Jiménez could do in few months in 1959 only affected some parts of it. Most importantly, the main interest of this document lies exactly in its in-betweenness. That is, the 1959 Geografía de Cuba was no longer a book conceived during the clandestine conspiration against the old regime, but it was not yet a state geography that could be a direct expression of the new authoritarian Marxist-Leninist regime, which was established only in the following years. This means that Jiménez's geography is relevant for its prefigurative (rather than normative) nature, and for its participation in a longer tradition of geographical representations anticipating social changes, which dates back to the 'civic geography' of Carl Ritter (17791859) and Alexander von Humboldt (1769-1859) as discussed by Franco Farinelli (1992). For Farinelli, this geography was an implicit political strategy to give cultural instruments to the rising European bourgeoisie for countering feudal aristocracy and prefiguring a new world by starting to represent its spaces outside established canons (Minca, 2007). In this sense, it is not surprising that Jiménez repeatedly acknowledged his debt to Humboldt, whose work he defined as an inspiration for 'poets, libertadores and naturalists' (Jiménez, 1982b:267), showing his awareness of the prefigurative potentialities of geography.

In his Introduction to Geografía de Cuba, Jiménez explicitly contended that, for 'these new times', a 'new geography' was needed (Jiménez, 1959:7). On the one hand, this was associated with environmental concerns, for instance the need for a geography fighting 'against erosion and allowing for the repopulation of the forests' (Jiménez, 1959:8). On the other, this responded to social and political concerns for the solution 'of the serious problems that our semi-colonial economy entails' (Jiménez, 1959:9). The geographer identified a clear continuity between the nineteenth-century war for national liberation and the struggle of his days, celebrating the figure of national hero Martí as the first person who had denied 'the historical geographical fatalism pretending that, close to a so strong nation as the United States, Cuba could never be

F. Ferretti, 2022: "Geographies of revolution: prefiguration and spaces of alterity in Latin American radicalism", Environment and Planning C, Politics and Space Online first: https://journals.sagepub.com/doi/full/10.1177/23996544211063163 [author's version] 
really independent' (Jiménez, 1959:18). Jiménez's geographical voluntarism is even more relevant if we consider contemporary concerns towards the coming back of determinist arguments in mainstream geopolitics.

Although without completely escaping from their theoretical framework, Jiménez derided European traditions of environmental determinism by sarcastically noticing how European authors repeatedly asserted 'the inferiority of Latin-Americans due to miscegenation, to the physical environment or to other causes' (Jiménez, 1959:22). Concurrently, he mobilised arguments serving the geographical 'invention' of the Cuban nation and insisted that Cuba should not be considered as an island, but as an archipelago. This was not a minutia of geographical nomenclature, but a key geopolitical point for claiming national recognition. The concept of archipelago allowed considering the submarine platform surrounding Cuba as an addition of '75,000 square kilometres' (Jiménez, 1959:32) to the territory subject to Cuban formal sovereignty. This argument was reiterated through Jiménez's contention that Cubans 'should see in their seas ... a continuation of their lands rather than a water frontier; they should feel the sea's life as something essential to their spirit' (Jiménez: 1959:329). While this 'feeling' accompanied Jiménez's call to Cuban fishers to join the cooperatives which had been created by the revolution to overtake their 'miserable condition' (Jiménez, 1959:337), such arguments mainly served to think different geopolitical rules allowing for (anti-colonial) sovereignty claims.

Arguments for Cuba's full sovereignty were mobilised all along the book, with implicit or explicit reference to North American imperialism, including the pages in which Jiménez reconstructed the country's history. Significantly, Batista's military coup of March 1952 was defined as 'an act of offended Fatherland (lesa Patria)' (Jiménez, 1959:194). Conversely, the revolution of January 1959 was deemed the accomplishment of Cuba's 'full sovereignty' (Jiménez, 1959:194). Cuban histories were likewise mobilised to build ideas of national pride on the bases of long anti-colonial struggles in which: 'No American people paid a higher price than the Cubans' (Jiménez, 1959:182). In the 1950s, these struggles paralleled claims for agrarian and social reforms to get rid of 'hunger, misery and despair' (Jiménez, 1959:208). The paradox of having 'a so rich country which is inhabited by a poor people' and where 'a minority

F. Ferretti, 2022: "Geographies of revolution: prefiguration and spaces of alterity in Latin American radicalism", Environment and Planning C, Politics and Space Online first: https://journals.sagepub.com/doi/full/10.1177/23996544211063163 [author's version] 
enjoys the wealth that is produced by the great majority' (Jiménez, 1959:207) was explained by economic dependency from North America, whose companies owned the mines, imposed the sugarcane monoculture, and hindered the development of Cuban manufactures.

These phenomena were well described by the Latin American literature on dependency theory that geographer David Slater defined as one of the most original theoretical contributions from the South to resolve Southern problems (Slater, 2004). Therefore, the fact that a relatively obscure Cuban geographer could elaborate these arguments paralleling works of more famous theorists such as Raúl Prebisch (1901-1986), reveals how the relevance of geography for dependency debates has been underplayed. For Jiménez, 'who controls the resources is the master of the country' (Jiménez, 1959:210); hence the need for the government to fully control these resources to avoid being 'dependent from a foreign power' (Jiménez, 1959:214). Cuba was compared by Jiménez to still 'slave Algeria' (Jiménez, 1959:218), evoking the war that was ongoing in Algeria for national liberation from France (1954-1962). Crucially, Cuba's situation of dependence was analysed by Jiménez in the context of long-lasting colonial economic relations, based on latifundium and monoculture.

Yet, the problems that Jiménez raised in his geography of revolution were not limited to the task of taking away sugar production from the control of North American corporations. For the geographer, 'the appropriation of the land by few landlords which is called latifundium is the evil of evils' (Jiménez, 1959:235). Crucially, Jiménez noted the hindrances that latifundia imposed to agricultural diversification, resulting in the impossibility, for most labourers, to cultivate any parcel of land for self-consumption. This led to paradoxes such as the import of black beans from the USA and exposed peasantry to hunger despite the productivity of land, an argument which echoed Josué de Castro's geography of hunger. For Jiménez, the sole solution was giving 'land to the people' (Jiménez, 1959:236), following Martí, who argued that monoculture was a 'suicide' (Jiménez, 1959:308). Yet, it looks like the Cuban government did not actually consider this suggestion when they started to sell sugarcane to the Soviet Union to circumvent the US embargo.

F. Ferretti, 2022: "Geographies of revolution: prefiguration and spaces of alterity in Latin American radicalism", Environment and Planning C, Politics and Space Online first: https://journals.sagepub.com/doi/full/10.1177/23996544211063163 [author's version] 
On environmental matters, Jiménez drafted a sort of socio-political ecology in denouncing the commodification and privatisation of natural assets such as woods and beaches, which had led to the gradual degeneration of what he called 'Cuban geographical landscape' (Jiménez, 1959:366). For new revolutionary Cuba, Jiménez conceived a new idea of tourism, one that he described in quite moralistic tones, being based on getting rid of 'some libertine millionaires and other people of doubtful moral' (Jiménez, 1959:368). In the previous decades, and especially during the Prohibition in the United States, they were mainly North Americans who considered Cuba as a safe harbour to avail of alcohol, prostitution, gambling and so on. Conversely, and somehow naively, Jiménez stressed the potentialities of the 'healthy' tourism that revolutionary Cuba wanted. 'Cuba ... can attract great masses of foreign tourists who are interested in knowing different nations, in resting, in hunting and fishing, in restoring their health, in contemplating marvellous landscapes' (Jiménez, 1959:369). While today this ideal seems far from being achieved, the reconversion of certain places to touristic uses had a symbolical value, as in the case of Isla de Pinos, which had been so 'bad treated and forgotten' (Jiménez, 1959:369) by the former governments, which used this island as a penal colony.

Across Jiménez's book, one finds key stories and anecdotes on the liberation of certain places by the Rebel Army, including excerpts of Jiménez's War Diary stressing the need that guerrillas make alliances with the civilians, paralleling Guevara's famous work La guerra de guerrillas (Guevara 1960). To highlight a rebel genealogy going from early anticolonialism to the 1959 revolution, Jiménez defined Camagüey as 'one of the first regions that rose in arms against the Spanish domination' (Jiménez, 1959:521) already in 1826, and then in 1868, to be finally the theatre of the operations led by Cienfuegos. The book includes descriptions of a guerrilleros' Free State, established in 1958, which covered an area of 12,000 square kilometres in the extreme east of the country, close to the legendary Sierra Maestra. Amazingly, discussing the 'geographical limits' of this free state, Jiménez noted that it had an 'international frontier' (Jiménez, 1959:521), namely with the infamous US base of Caimanera, near Guantanamo.

This led to the earliest diplomatic incident between the guerrillas and the United States, which was indeed described by Jiménez as a victory for the Revolution, consisting in: 'The detention of half-hundred North American citizens, for making them witness the savage bombings of the

F. Ferretti, 2022: "Geographies of revolution: prefiguration and spaces of alterity in Latin American radicalism", Environment and Planning C, Politics and Space Online first: https://journals.sagepub.com/doi/full/10.1177/23996544211063163 [author's version] 
Tyranny's airplanes, equipped with North American bombs and gun-machines' (Jiménez, 1959:605). This was necessary, for Jiménez, to make the world know that: 'A new free and independent republic was coming into the world in the Oriente's mountains' (Jiménez, 1959:605). As I explain in the next section, these mountains and woods were key spaces of alterity and resistance in Jiménez's geography of revolution, providing new insights to insert 'other' spatialities in the analytical framework of critical and decolonial geopolitics.

\section{3- Spaces of alterity: the geopolitics of the Monte}

James C. Scott has famously argued that civilisation (understood as political power) 'cannot climb hills' (Scott, 2009:20). In most of the Spanish-speaking countries of Latin America, the term Monte (mountains) indicates the 'uncivilised' countryside, inhabited by people such as indios, quilombolas/cimarrones and guerrilleros in opposition to 'civilised' and policed plains and cities. In Cuba, this myth was associated with the guerrilla operations in the Sierra Maestra. This section discusses and problematises Jiménez's attempts, performed in his Geografía de Cuba and in later works such as La Comida en el Monte: cimarrones, mambises y rebeldes, to claim direct continuity between the early insurgence of the cimarrones (Black slaves fleeing from plantations and organising autonomous communities in the bush), the mambises (fighters of the nineteenth-century independence wars), and contemporary guerrillas. Again, Jiménez's work was not devoid of limits and contradictions, as the materials quoted below are gathered from limited parts of some books that are overwhelmingly descriptive or documentary. There, Jiménez seems to express his own views only in introductions and marginalia, revealing that his mindset was still conditioned by the frameworks of some geographical positivism, although his fascination for insurgent traditions made the geographer discuss cases which can nourish current decolonial debates challenging Eurocentric knowledge.

While the historical importance of marronage is increasingly recognised by Latin American and international scholarship (Cowling, 2013; Guillen, 2021; Roberts, 2015; Schwarcz and Gomes, 2018), to understand Jiménez's references to these insurgent histories it is necessary to consider the complex debates on race and discrimination that characterise Cuban historiography. Cuba is geographically very close to Haiti, where the most famous revolution of Black slaves took place from 1791 to 1804 . Yet, as Ferrer demonstrated, 'liberation in Saint-

F. Ferretti, 2022: "Geographies of revolution: prefiguration and spaces of alterity in Latin American radicalism", Environment and Planning C, Politics and Space Online first: https://journals.sagepub.com/doi/full/10.1177/23996544211063163 [author's version] 
Domingue helped entrench its denial in Cuba. As slavery and colonialism collapsed in the French colony, the Spanish island underwent transformations that were almost the mirror image of Haiti's' (Ferrer, 2014:10). Thus, Cuba managed to prevent the revolutionary threat and to take Haiti's place as the main producer of sugarcane and one of the most active importers of slaves. According to Ferrer, the fear of slaves' revolts that obsessed the creole bourgeoisie contributed to delay Cuba's independence from Spain. Indeed, the national liberation struggle, staged in the three revolts of 'the Ten Years' War (1868-78), the Guerra Chiquita, or Little War (1879- 80), and the final War of Independence (1895-98) which ended with the SpanishAmerican War' (Ferrer, 1999:3) saw an outstanding participation of Afro-Cubans in the Liberation Army. For Ferrer: 'Historians estimate that at least 60 percent of that army was composed of men of colour' (Ferrer, 1999:3). Concurrently, 'runaway slaves organized themselves into maroon-style communities, sometimes providing food for insurgent camps' (Ferrer, 1999:74).

Ferrer highlights the anti-racist claims of Martí, who denied the very notion of race considering that it was a tool to divide people who should be united in the anti-colonial struggle. Similar positions characterised the anarchist movement, where 'the rise of prominent Afro-Cubans ... in the 1910s and 1920s' (Shaffer, 2019:100) paralleled efforts to fight racism on scientific and educational bases, for instance by trying to convince students to 'reject craniology and recognize that blacks and whites were first and foremost equal human beings' (Shaffer, 2019:90). Although praiseworthy, the idea of building equality by rejecting the notion of race entailed further problems. While in the period from 1902 Cuba's formal independence from the United Stated (since 1898 from Spain) to the 1959 Revolution, equality was far from being established, the pretention of the new revolutionary regime that the socialist revolution had automatically erased all racial issues resulted likewise delusional.

Although socialist Cuba made important steps towards inclusion after 1959, Alejandro de la Fuente notices the ambivalence of Castro's regime since the times of the M26J, in whose programme, 'race and discrimination did not figure prominently' (Fuente, 2001:260). While Fidel overtly condemned racial discrimination, he was very cautious in passing formal antidiscrimination laws to avoid puzzling some parts of the Creole bourgeoisie that were not

F. Ferretti, 2022: "Geographies of revolution: prefiguration and spaces of alterity in Latin American radicalism", Environment and Planning C, Politics and Space Online first: https://journals.sagepub.com/doi/full/10.1177/23996544211063163 [author's version] 
opposed to his government but were instead afraid of racial equality. Moreover, for Fuente: 'By the mid-1960s the Afro-Cuban societies were being perceived by the revolutionary government as hindrances to its agenda' (Fuente, 2001:260). Accordingly, the publication of a specific Black press was forbidden, based on the allegation that it was not needed given that discrimination had already disappeared under the revolutionary rule. Danielle Clealand defines these polices as 'racial paternalism' (Clealand, 2017:2), which was widely deployed in governmental rhetoric's while: 'Inequality remains a reality in contemporary Cuba and the persistence of racist practices ... contradicts the sustained assertion of its absence by the government' (Clealand, 2017:2). Several contradictions characterised these policies, such as the declaration of the "participation in Afro-Cuban religions as "pathological behaviour" (Fuente, 2001:295) by the Cuban Ministry of Health.

However, the regime could not strictly control all cultural expressions. Clealand defines the works of an Afro-Cuban poet, Nicolás Guillén (1902-1989), as 'a challenge to the dominant ideas around racial mixture' and an autonomous expression of 'black pride' (Clealand, 2017:57). While this could be somehow subsumed in the official propaganda, and Guillén was not considered as a dissident by the Castroist regime to the best of my knowledge, it is possible to hypothesise that some spaces for free cultural expressions and their circulation remained available at the margins of the regime. It is worth noting that Jiménez claimed his friendship with Guillén, who wrote that being a geographer was 'one of the finest ways of being a poet' (Jiménez, 1982b:10) referred to another impressive work of Jiménez, Geopoética.

In his geographical work and transnational networking mentioned above, Jiménez contributed to the official task of valuing African cultures to make alliances with African neo-decolonised countries and even Black movements in North America. However, to Clealand, this participated in a general politic of homogeneity that 'neglects racial and cultural diversity' (Clealand, 2017:55), erasing the importance of blackness, although the image that revolutionary Cuba exported 'was largely defined by its African ancestry' (Fuente, 2001:290). On the issue of homogeneity, Geografía de Cuba exposed rather ambivalent positions. On the one hand, Jiménez harshly denounced the 'barbarity' (Jiménez, 1959:182) of the 'abominable' (Jiménez, 1959:183) slave trade claiming that: 'Repugnant and antipatriotic, racial

F. Ferretti, 2022: "Geographies of revolution: prefiguration and spaces of alterity in Latin American radicalism", Environment and Planning C, Politics and Space Online first: https://journals.sagepub.com/doi/full/10.1177/23996544211063163 [author's version] 
discrimination does not make sense in a republic which is based on the emancipatory brotherhood of Whites, Blacks and Asians. Instigating any division of Cuba means to debilitate the Fatherland's body before the limitless ambitions of monopolist and imperialist powers' (Jiménez, 1959:183). On the other, he discussed ideas of miscegenation and transculturation which went beyond mere assimilationism, by defining a Cuban identity as the result of miscegenation, highlighting the direct filiation of Afro-Cuban music from early 'African drums' (Jiménez, 1959:176) and stressing the 'contributions' (Jiménez, 1959:183) and 'influences' (Jiménez, 1959:202) that Cuba received from Africa. He even evoked some cultural influxes of people escaping to Cuba from 'Haitian struggles for independence' (Jiménez, 1959:202).

In La Comida en el Monte, Jiménez endorsed early Afro-Cuban insurgency by analysing the food that characterised the Monte's lifestyle as a marker of both its cultures and physical environments. Already in Geografía de Cuba, Jiménez had noticed that the mambises mainly ate 'palmitos' (Jiménez, 1959:277), to confer a certain nobility to this food, as it was eaten by Cuban anticolonial heroes. For Jiménez, these heroes also honoured another food, which had been a symbol of the Haitian 1791 revolt after the sacrifice of a pig during the historical assembly of Bwa Kayiman (Ferrer, 2014): 'Pork meat was always the preferred one for the insurgents' (Jiménez, 1998d:10). For writing La Comida en el Monte, Jiménez interviewed some of the last surviving cimarrones who had fled from plantations before slavery was abolished in the 1880s, including one Esteban Montejo who served in the Ejercito Libertador in 1895 , to highlight the historical continuity between all of these experiences, within the spatial imaginaries of the Monte. These survivors proudly recounted how they used to steal suckling pigs in the Withes' farms, making the experience of rebellion tasty in all senses-a true adventure which took place between forests and mountains.

Individual insubordination became suddenly part of wider insurgencies at the point that, before the end of slavery, 'the defeat of being a cimarrón' (Jiménez, 1998e:9) was a typical reference for a slave to be sold in the markets. A monograph that Jiménez entirely dedicated to the history of slavery in Cuba, Los Esclavos Negros, reproduced an impressive amount of archival documentation of racist oppression and violence in modern Cuba. Conversely, the author

F. Ferretti, 2022: "Geographies of revolution: prefiguration and spaces of alterity in Latin American radicalism", Environment and Planning C, Politics and Space Online first: https://journals.sagepub.com/doi/full/10.1177/23996544211063163 [author's version] 
highlighted the frequency of revolts such as "that of May 1843 in the farm La Alcancía" (Jiménez, 1998e:173), mobilising hundreds of slaves. Jiménez analysed also the complex and federal social organisation of some palenques, the communities of fleeing slaves (like the Brazilian quilombos) that sometimes reached prominence and even flourished economically in the same eastern region that was later the theatre of Cuban guerrilla.

Connecting these racial debates with myths of indigenous insurgence, Jiménez's geopolitics of the Monte contributed to revolutionary propaganda by defining the mountains of the Sierra Maestra as the 'cradle of national independence' (Jiménez, 1959:14) and 'bastion of Cuba's freedom' (Jiménez, 1959:152). There, Jiménez matched a classical Romantic idea of the mountains as the refuge of liberty which was not extraneous to the tradition established by Humboldt (Farinelli, 2003). In Geografía de Cuba, Jiménez denounced the Indios' genocide by early Spanish Conquistadores, whose 'barbarity ... submitted the Indios to a limitless exploitation, almost completely exterminating them' (Jiménez, 1959:176). The geographer also highlighted the inhuman nature of forced labour in the plantations, arguing that those enslaved Indios who did not die for these mistreatments adopted extreme forms of insubordination such as suicide or escape 'in the archipelago's tough mountains' (Jiménez, 1959:211). Although Jiménez did not treat very extensively histories of indigenous insurgence in this work, arguably for a lack of sources, these notes clearly show how his genealogy of Cuban rebellions included insubordination of first peoples again Spanish invaders.

In any case, the emphasis that Jiménez placed in stories of Indio and Black agency (rather than mere assimilation) served to stress the continuity between early anti-colonial insurgency and the 1958 guerrilla, all of these taking place in the Monte. 'Since conquest and colonisation ... in Cuba, constant manifestations of rebellion appeared against the injustices ... from slavery to modern imperialism. The struggle for individual and social emancipation found its main scenario in the natural contours of the Cuban fields. Indios, Blacks, Mambises and guerrillas had to adapt, for five centuries, to the life conditions [of] their tropical nature' (Jiménez, 1998d:9). Jiménez's long-term historical comparison between these four categories of fighters and their spatiality in the Monte clearly chimes with Wright's arguments mentioned above.

F. Ferretti, 2022: "Geographies of revolution: prefiguration and spaces of alterity in Latin American radicalism", Environment and Planning C, Politics and Space Online first: https://journals.sagepub.com/doi/full/10.1177/23996544211063163 [author's version] 
In the Monte, unruly Indios and Africans were traditionally favoured by the terrain, which rendered difficult to recapture them. Later, these environmental characteristics were exploited by the guerrillas, as explicitly claimed by Fidel Castro arguing that: 'Nature was our ally' (Jiménez, 1982a:448). In Jiménez’s writings, nature was described in very idealised terms evoking the 'love' of the fighters for their mountains and for a nature that was perceived 'as a living being' (Jiménez, 1982a:446). Therefore, Jiménez's point in deeming mountains good for guerrilla was not only geo-strategic or geo-political, but also cultural, targeting the 'invention' of a Cuban national identity to be strictly associated with the island's landscapes. This approach complicates discourses on cultural homogenisation, because in matters of blackness Jiménez seemed to give more importance to culture and identity than the official propaganda discourses. Beyond mere assimilation, his idea of 'transculturation' (Jiménez, 1982a:446), including the 'fusion of Western-Arab culture with the Indo-Cuban and the African' (Jiménez, 1982a:446) drew upon subaltern resistance that took place in spaces of alterity. Not bounded, but rather defined by natural-cultural qualities, these 'other' spaces can make sense of plurality as a key feature of Latin-American prefigurative geographies of revolution.

\section{Conclusion}

This work has shown the overwhelming anticolonial nature of Jiménez's geography of Cuba and its contribution to construct a national anticolonial imagination for the new socialist nation. As discussed above, the 1959 edition of this book was an expression of the short period in which the Cuban Revolution was still pluralistic. Crucially, over 624 pages, Jiménez never mentioned authors such as Marx, Engels, Lenin or Gramsci, although expressing antiimperialistic and socialistic purposes through the ideas of land reform and distribution of wealth. Following Shaffer, socialism is not synonymous with Marxism: while this idea chimes with anarchist claims that the establishment of a centralistic political power suffocates the original elan of revolutions, it also indicates how geographies of revolution, in their performativity, are often resistant to assume strict ideological orthodoxies. When revolutions still have to be institutionalised, geography of revolution is about prefiguring a different world rather than bounding, regulating and administrating it: in these last cases, it would become geography of statehood. In all cases, geography helps understanding the diversity of

F. Ferretti, 2022: "Geographies of revolution: prefiguration and spaces of alterity in Latin American radicalism", Environment and Planning C, Politics and Space Online first: https://journals.sagepub.com/doi/full/10.1177/23996544211063163 [author's version] 
revolutions, which take place in different forms in different spaces as Withers, Livingstone and Heffernan contend.

Early utopian inspirations clash with the historical limitations of the Cuban experience, especially after the 1961 'communist' turn, including authoritarianism, a masculinist rhetoric that was constructed around the myth of the barbudos, male and bearded fighters (a category to which Jiménez fully belonged), and finally the contradictions on issues of race that are discussed above. However, geography could still circulate different contents. It was the case with Jiménez's elaborations on the Monte, written in times when he was already an established 'state geographer' rather than a subversive. While Jiménez's works on the cimarrones were phrased in a way that could not contradict official Castroist propaganda, his ideas of the Monte can provide insights to thinking about geopolitics beyond territory and to construct different grammars of space as suggested by authors like Minca.

Beyond his works' limits and ambivalences noted above, Jiménez wrote a revolutionary geography that can still contribute to a decolonial geopolitics by addressing continuity between early anti-colonial insurgency and the 1958 guerrilla within the spaces of alterity that are constituted by the Monte, where different territorial relations exist. These geographies provide elements to think space decolonially, complicating classical European notions of territory as bounded space subject to a political power. The idea of the Monte as a space of alterity and insubordination belongs to culture, history and ethics rather than to topography and geomorphology. It defines insurgent spaces whose definition can match contemporary LatinAmerican claims for territory as a notion of resistance and calls for thinking places in relational rather than statist/static terms (Zibechi 2012; Halvorsen, 2019; Halvorsen, Fernandes and Torres, 2019). It can enrich geography by including ideas and practices from non-European cultures, especially those of Indios and rebel slaves who took advantage of the most remote lands of the 'New World'. Considering these legacies helps to decolonise geography and geopolitics by involving new languages, people and traditions in disciplinary conversations.

F. Ferretti, 2022: "Geographies of revolution: prefiguration and spaces of alterity in Latin American radicalism", Environment and Planning C, Politics and Space Online first: https://journals.sagepub.com/doi/full/10.1177/23996544211063163 [author's version] 


\section{Acknowledgements}

For this paper, I have to first acknowledge my Mexican colleagues and friends, especially Verónica Ibarra García, Héctor Mendoza Vargas and Gerónimo Barrera de la Torre who first called my attention to the works of some Spanish-speaking critical geographers including Jiménez and Bassols-Batalla during my visits to Mexico in past years. Many thanks also to the librarians of the State Library of the Republic of San Marino, where I amazingly found one of the richest collections of Jiménez's books available in Europe, which spared me further travels to access my sources. Special thanks also to the three anonymous referees for EPC for their precious suggestions, that decisively helped me in improving my paper, and to the Editor, Patricia Daley.

\section{References}

Agnew J (2010) Still trapped in territory? Geopolitics 15:779-784.

Anderson B (1991) Imagined Communities: Reflections on the Origin and Spread of Nationalism. London:Verso.

Anderson B (2007) Under Three Flags: Anarchism and the Anticolonial Imagination. London:Verso.

Barnes T and Sheppard E (eds.) (2019) Spatial Histories of Radical Geography. Oxford:Wiley. Buck-Morss S (2009) Hegel, Haiti and Universal History. Pittsburgh:University of Pittsburgh Press.

Clayton D (2020) The passing of 'Geography's Empire' and question of geography in Decolonization, 1945-1980. Annals of the American Association of Geographers, 110(5):1540-1558.

Clealand DP (2017) The Power of Race in Cuba: Racial Ideology and Black Consciousness During the Revolution. Oxford:Oxford University Press.

Cowling C (2013) Conceiving Freedom: Women of Color, Gender, and the Abolition of Slavery in Havana and Rio de Janeiro. Chapel Hill:The University of North Carolina Press.

Craggs R (2018) Subaltern geopolitics and the post-colonial Commonwealth, 1965-1990. Political Geography 65:46-56.

Craggs R and Neate H (2020) What happens if we start from Nigeria? Diversifying histories of geography. Annals of the American Association of Geographers 110(3):899-916.

F. Ferretti, 2022: "Geographies of revolution: prefiguration and spaces of alterity in Latin American radicalism", Environment and Planning C, Politics and Space Online first: https://journals.sagepub.com/doi/full/10.1177/23996544211063163 [author's version] 
Davies A (2019) Josué de Castro's Geografia Combatente and the Political Ecology of Hunger. PhD thesis. King's College London.

Delgadillo J (2015) Por una Geografia humanista: Angel Bassols-Batalla. Mexico:UNAM.

Elden S (2013) The Birth of Territory. Chicago:The University of Chicago Press.

Farber S (2006) The Origins of the Cuban Revolution reconsidered. Chapel Hill:University of North Carolina Press.

Farinelli F (1992) I segni del mondo. Florence:La Nuova Italia.

Farinelli F (2003) Geografia. Turin:Einaudi.

Fernández F (2001) Cuban Anarchism: The History of a Movement. Tucson:See Sharp Press [retrieved from: https://theanarchistlibrary.org/library/frank-fernandez-cuban-anarchism-thehistory-of-a-movement]

Ferrer A (1999) Insurgent Cuba: Race, Nation, and Revolution 1868-1898. Chapel Hill:The University of North Carolina Press.

Ferrer A (2014) Freedom's Mirror: Cuba and Haiti in the Age of Revolution. Cambridge:Cambridge University Press.

Ferretti F (2018) Teaching anarchist geographies: Elisée Reclus in Brussels and 'the art of not being governed'. Annals of the American Association of Geographers 108(1):162-178.

Ferretti F (2021) A coffin for Malthusianism: Josué de Castro's subaltern geopolitics. Geopolitics 26(2):589-614.

Ferretti F and Pedrosa BV (2018) Inventing critical development: a Brazilian geographer and his Northern networks. Transactions of the Institute of the British Geographers 43(4):703-717. Fuente A (2001) A Nation for All: Race, Inequality, and Politics in Twentieth Century Cuba. Chapel Hill:The University of North Carolina Press.

Guevara E (1960) La guerra de guerrillas. Habana:MINFAR.

Guillen ALZ (2021) Afro-Latin American geographies of in-betweenness: colonial marronage in Colombia. Journal of Historical Geography 72:13-22.

Halvorsen S (2019) Decolonizing territory: dialogues with Latin America knowledges and grassroots strategies. Progress in Human Geography 43(5):790-814. Halvorsen B, Fernandes D and Torres FV (2019) Mobilising territory: Socioterritorial movements in comparative perspective. Annals of the Association of American Geographers, 109(5):1454-1470.

F. Ferretti, 2022: "Geographies of revolution: prefiguration and spaces of alterity in Latin American radicalism", Environment and Planning C, Politics and Space Online first: https://journals.sagepub.com/doi/full/10.1177/23996544211063163 [author's version] 
Heffernan M (2005) Edme Mentelle's geographies and the French revolution. In Livingstone DN and Withers CWJ (eds.) Geography and Revolution. Chicago:The University of Chicago Press, 273-303.

Hooson D (ed) (1994) Geography and National Identity. Oxford:Blackwell.

Ibarra MV and Sánchez ET (2020). Pioneers in Latin American critical geographies, Josué de Castro and Antonio Nuñez-Jimenez. In Schelhaas B, Ferretti F, Novaes A and Schmidt M (eds.). pp. 17-26. Decolonising and Internationalising Geography: Essays in the History of Contested Science. Berlin:Springer, 17-26.

Ince A and Barrera GT (2016) For post-statist geographies. Political Geography 55:10-19.

James CRL (1938) The Black Jacobins, Toussaint L'Ouverture and the San Domingo Revolution. London:Secker \& Warburg.

Jiménez AN (1959) Geografía de Cuba. Habana:Editorial Lex.

Jiménez AN (1982a) Cuba: la naturaleza y el hombre. 1. El archipiélago. Habana:Editorial Letras Cubanas.

Jiménez AN (1982b) Cuba: la naturaleza y el hombre. 2. Geopoética. Habana:Editorial Letras Cubanas.

Jiménez AN (1998ª) Hacia una cultura de la naturaleza. Habana:Editorial de Ciencias Sociales.

Jiménez AN (1998b). En marcha con Fidel, 1959. Habana:Editorial de Ciencias Sociales. Kindle Edition.

Jiménez AN (1998c) En marcha con Fidel, 1960. Habana:Editorial de Ciencias Sociales. Kindle Edition.

Jiménez AN (1998d) La comida en el monte: cimarrones, mambises y rebeldes. Habana:Editorial de Ciencias Sociales.

Jiménez AN (1998e) Los esclavos negros. Habana:Editorial de Ciencias Sociales.

Kapcia A (2014) Leadership in the Cuban Revolution: The Unseen Story. London:Zed Books. Kempf A (2014) Post-Racialism in the classroom as anti-racist praxis in Cuba? Latin American and Caribbean Ethnic Studies, 9(1):44-64.

Livingstone DN and Withers CWJ (eds.) (2005) Geography and Revolution. Chicago:The University of Chicago Press.

F. Ferretti, 2022: "Geographies of revolution: prefiguration and spaces of alterity in Latin American radicalism", Environment and Planning C, Politics and Space Online first: https://journals.sagepub.com/doi/full/10.1177/23996544211063163 [author's version] 
Mahler AG (2018) From the Tricontinental to the Global South, Race, Radicalism, and Transnational Solidarity. Durham and London:Duke University Press.

McConnell F (2016) Liminal geopolitics: the subjectivity and spatiality of diplomacy at the margins. Transactions of the Institute of British Geographers 42:139-152.

McKelvey C (2017) The Evolution and Significance of the Cuban Revolution: The Light in the Darkness. Basingstoke:Palgrave Macmillan.

Mignolo W and Escobar A (2010) (eds.) Globalization and the Decolonial Option. London:Routledge.

Minca C (2007) Humboldt's compromise, or the forgotten geographies of landscape. Progress in Human Geography 31:179-193.

Minca C (2019) Geografia e rivoluzione. Rivista Geografica Italiana 126:7-20.

Noxolo P (2017) Decolonial theory in a time of the re-colonisation of UK research. Transactions of the Institute of British Geographers 42:342-344.

Radcliffe (2017) Decolonising geographical knowledges. Transactions of the Institute of British Geographers 42:329-333.

Reclus E (1908) L'Homme et la Terre, 6. Paris:Librairie universelle.

Reid-Henry S (2010) The territorial trap fifteen years on. Geopolitics 15:752-756.

Roberts N (2015) Freedom as marronage. Chicago:The University of Chicago Press.

Schwarcz LM and Gomes FS (2018) (eds.) Dicionário da escravidão e liberdade. [São Paulo]:Companhia das Letras.

Scott J (2009) The Art of Not Being Governed, an Anarchist History of Upland Southeast Asia. New Haven:Yale University Press.

Shaffer K (2019) Anarchist Cuba: Countercultural Politics in the Early Twentieth Century. Oakland:PM Press.

Sharp J (2011). Subaltern geopolitics: Introduction. Geoforum 42: 271-273.

Shilliam R (2017) Race and revolution at Bwa Kayiman. Journal of International Studies 45(3):269-292.

Sidaway JD, Mamadouh V and Power M (2013). Reappraising geopolitical traditions. In Dodds K, Kuus M and Sharp J (eds.) The Ashgate Research Companion to Critical Geopolitics. Farnham:Ashgate, 165-87.

Skierka V (2004) Fidel Castro: A Biography. Oxford:Polity.

F. Ferretti, 2022: "Geographies of revolution: prefiguration and spaces of alterity in Latin American radicalism", Environment and Planning C, Politics and Space Online first: https://journals.sagepub.com/doi/full/10.1177/23996544211063163 [author's version] 
Slater D 2004 Geopolitics and the Post-colonial: Rethinking North-South Relations. Malden:Blackwell.

Souza ML (2016), Lessons from Praxis: autonomy and spatiality in contemporary Latin American social movements. Antipode 48(5):1292-1316.

Thomas H (1971) Cuba: The Pursuit of Freedom. New York:Harper and Row.

Volin (2019) The Unknown Revolution: 1917-1921. Oakland:PM.

Wright WJ 2020 The morphology of marronage. Annals of the American Association of Geographers 110(4):1134-1149.

Zibechi R (2012) Territories in Resistance: A Cartography of Latin American Social Movements. Edinburgh:AK Press.

F. Ferretti, 2022: "Geographies of revolution: prefiguration and spaces of alterity in Latin American radicalism", Environment and Planning C, Politics and Space Online first: https://journals.sagepub.com/doi/full/10.1177/23996544211063163 [author's version] 